\title{
Analisis Pengaruh E-Service Quality, Perceived Value Terhadap Customer Satisfaction, Trust, dan Customer Behavioral Intention (Survei pada Customer Toko Online www.blibli.com)
}

\author{
William Ciputra ${ }^{1}$ dan Wibawa Prasetya ${ }^{2}$ \\ ${ }^{1,2}$ Universitas Katolik Indonesia Atma Jaya, Jakarta, Indonesia
}

\begin{abstract}
ABSTRAK
Pada survei popularitas e-commerce di Indonesia, e-commerce Blibli menempati peringkat pertama di media sosial, namun jumlah pengunjung/bulan dari Blibli ini lebih rendah daripada peringkat ke-2 dan ke-3 pada peta e-commerce. Beberapa hal yang mempengaruhi tingkat penjualan dari suatu perusahaan e-commerce, yaitu seperti e-service quality, perceived value dan satisfaction dari customer. Selain itu menurut Mayer et al. (1995) "trust is central in e-commerce relationships because of the presence of risks, uncertainties, and interdependencies". Berdasarkan uraian tersebut, penelitian ini bertujuan mengetahui bagaimana hubungan antara e-service quality dan perceived value terhadap customer satisfaction, trust, dan behavioral intention customer e-commerce Blibli. Penelitian ini dilakukan dengan cara menyebarkan kuesioner yang sudah diuji validitas dan reliabilitas kepada 200 responden. Data yang didapatkan kemudian diolah menggunakan metode SEM (Structural Equation Modelling) dengan aplikasi LISREL (LisWin32). Hasil pengolahan data menunjukkan bahwa variabel e-service quality memiliki pengaruh positif yang signifikan terhadap perceived value, variabel e-service quality tidak memiliki pengaruh positif yang signifikan terhadap customer satisfaction, variabel perceived value memiliki pengaruh positif yang signifikan terhadap customer satisfaction, variabel e-service quality tidak memiliki pengaruh positif yang signifikan terhadap trust, variabel perceived value tidak memiliki pengaruh positif yang signifikan terhadap trust, variabel customer satisfaction tidak memiliki pengaruh positif yang signifikan terhadap trust, variabel e-service quality tidak memiliki pengaruh negatif yang signifikan terhadap behavioral intention, variabel perceived value tidak memiliki pengaruh positif yang signifikan terhadap behavioral intention, variabel trust tidak memiliki pengaruh positif yang signifikan terhadap behavioral intention.
\end{abstract}

Kata kunci: e-service quality; perceived value; customer satisfaction; trust; behavioral intention

\begin{abstract}
In popularity e-commerce survey in Indonesia, Blibli e-commerce ranked first in social media, but number of visitors per month blibli is lower than e-commerce in ranked second and third. Several things that affect sales in e-commerce is e-service quality, percevied value, and customer satisfaction. Furthermore, according to Mayer et al. (1995) "trust is central in e-commerce relationships because of the presence of risks, uncertainties, and interdependencies". Based on that description, this research's purpose is to discover relationship between e-service quality and perceived value toward customer satisfaction, trust, and behavioral intention blibli's customer. This research is done by distributing questionnaires that had passed validation and reliability test to 200 respondents. For which is was carried out by using Structural Equation Modelling method with LisWin application. The result show that e-service quality have a significant positive effect to perceived value, e-service quality don't have a significant positive effect to customer satisfaction, perceived value have a significant positive effect to customer satisfaction, e-service quality don't have a significant positive effect to trust, perceived value don 't have a significant positive effect to trust, e-service quality don't have a significant
\end{abstract}

CONTACT William Ciputra. Fakultas Teknik, Universitas Katolik Indonesia Atma Jaya Jakarta. Jl. Jend. Sudirman No.5, RT.5/RW.4, Jakarta Selatan 12930, Indonesia.w.ciputra@yahoo.co.id.

ARTICLE HISTORY Submitted: December 2020, Accepted: December 2020, Published: December 2020 
negative effect to behavioral intention, perceived value don't have a significant positive effect to behavioral intention, trust don't have a significant positif effect to behavioral intention.

Keywords: e-service quality; perceived value; customer satisfaction; trust; behavioral intention

\section{PENDAHULUAN}

Teknologi komunikasi di dunia sekarang berkembang dengan pesat. Perkembangan yang cepat ini memulai era baru yang disebut sebagai era digital. Era digital telah membuat manusia memiliki gaya hidup serba elektronik. Dengan teknologi yang ada sekarang, memudahkan manusia melakukan berbagai pekerjaan dengan cepat. Salah satu dampak dari era digital ini adalah electronic commerce (e-commerce). E-commerce atau perdagangan elektronik adalah aktivitas penyebaran, pemasaran, dan jual beli barang dan jasa melalui media elektronik (internet).

Berdasarkan survei popularitas e-commerce di Indonesia, e-commerce Blibli menempati peringkat pertama di media sosial, namun jumlah pengunjung/bulan dari Blibli ini lebih rendah daripada peringkat ke-2 dan ke-3 pada peta e-commerce. Blibli.com merupakan salah satu $E$ commerce di Indonesia berkonsep online shopping mall.

Terdapat beberapa hal yang mempengaruhi tingkat penjualan dari suatu perusahaan $e$ commerce, yaitu seperti $e$-service quality dan perceived value dari customer. E-service quality dan perceived value ini akan menjadi bahan pertimbangan bagi customer dalam memiliki perusahaan e-commerce mana yang akan mereka pilih.

Menurut Mayer et al. (1995), "trust is central in e-commerce relationships because of the presence of risks, uncertainties, and interdependencies". Berdasarkan kutipan tersebut, dijelaskan bahwa kepercayaan merupakan pusat dari suatu e-commerce. Hal ini dipengaruhi oleh kegiatan jual beli pada e-commerce dimana penjual dan pembeli tidak melakukan kegiatan jual beli secara langsung (tatap muka) yang kemudian dapat menimbulkan sebuah risiko bagi kedua pihak (penjual dan pembeli).

Beberapa hal lainnya yang penting untuk diperhatikan oleh perusahaan bisnis adalah kepuasan pelanggan (customer satisfaction). Kepuasan pelanggan adalah suatu pengukuran jenjang di mana kebutuhan, keinginan dan harapan dari pelanggan dapat terwujud yang kemudian mengakibatkan adanya pengulangan aktivitas pembelian atau loyalitas yang berkelanjutan. Berdasarkan hal tersebut, kepuasan pelanggan memberikan efek yang positif terhadap perusahaan e-commerce sehingga penting untuk ditingkatkan.

Salah satu metode yang digunakan untuk meneliti permasalahan yang terjadi pada perusahaan e-commerce Blibli.com ini adalah Structural Equation Modeling (SEM). Metode SEM ini cocok untuk digunakan karena variabel-variabel yang ingin diteliti merupakan variabel laten, dimana variabel-variabel ini tidak dapat diukur secara langsung (e-service quality, perceived 
value, customer satisfaction, trust, dan behavioral intention). Metode SEM juga dapat digunakan untuk mengukur efek hubungan-hubungan yang ada secara teoritis.

Berdasarkan uraian di atas, maka diperlukan penelitian apakah terdapat keterhubungan antara pelayanan pelanggan (e-service quality), penilaian pelanggan (perceived value), terhadap kepuasan pelanggan (customer satisfaction), kepercayaan pelanggan (trust), dan niat berperilaku customer (behavioral intention) pada perusahaan e-commerce Blibli.com menggunakan metode Structural Equation Model (SEM) dengan aplikasi LISREL.

\section{KAJIAN PUSTAKA}

\section{E-Service Quality}

Santos (2003) mengartikan kualitas e-service dengan evaluasi keseluruhan dari pelanggan mengenai kualitas dari pelayanan elektronik yang sangat baik atas pengalaman pelanggan di pasar online. Wilson et al. (2012) menjelaskan kualitas e-service dari sejauh mana website dapat menyediakan fasilitas untuk pelanggan dengan efektif dan efisien ketika berbelanja produk atau jasa, pembelian, dan hingga pengiriman produk atau jasa.

\section{Perceived Value}

Syamsiah (2009) menuturkan bahwa perceived value atau persepsi nilai sebagai akibat atau berbagai keuntungan yang didapatkan pelanggan dan perbandingannya terkait biaya keseluruhan yang dikeluarkan, meliputi juga harga pembelian dan biaya lainnya dalam suatu proses pembelian. Kotler (2013) menjelaskan bahwa perceived value merupakan selisih antara manfaat yang dinilai pelanggan akan mereka dapatkan dengan keseluruhan biaya yang harus dikeluarkan akan suatu penawaran dibandingkan dengan pilihian alternatif yang ada. Lalu, Holbrook (1994) mendefinisikan persepsi nilai sebagai langkah awal suksesnya transaksi yang memotivasi pelanggan untuk kembali melakukan pembelian.

\section{Customer Satisfaction}

Menurut Ariyanto (2003), kepuasan pelanggan adalah salah satu cara untuk meningkatkan loyalitas konsumen suatu perusahaan. Kepuasan pelanggan berpengaruh dalam meningkatkan kesetiaan pelanggan, mengurangi adanya elastisitas harga, melindungi pangsa pasar dari kompetitor, menurunkan biaya yang diperlukan untuk menarik pelanggan baru, dan menaikkan tingkat reputasi dihadapan pelanggan. Ho \& Lee (2007) menuturkan bahwa pengukuran tingkat kepuasan pelanggan dapat dilakukan saat proses pembelian ulang oleh pelanggan terjadi secara daring pada portal situs web dengan pemilihan yang tepat dan merasa terpuaskan setiap kali telah berbelanja dalam situs web.

\section{Trust}

Moorman et al. (1993) mendefinisikan trust sebagai suatu keinginan untuk bergantung pada mitra yang dapat dipercayai. Sedangkan, Lau \& Lee (1999) berpendapat bahwa trust menunjukkan kesediaan seseorang untuk memasrahkan dirinya pada pihak lain dengan risiko tertentu. Dapat dicontohkan dengan, kepercayaan akan suatu merek sebagai akibat dari pengalaman yang terjadi dari interaksi yang dialami di masa lalu. 


\section{Behavioral Intention}

Hansen \& Mowen (2012) menjelaskan behavioral intention atau niat perilaku sebagai keinginan pelanggan dalam bertindak dengan cara tertentu, yang bertujuan untuk kepemilikan, pembuangan, dan penggunaan produk atau jasa. Peter \& Olson (2008) menerangkan niat perilaku sebagai sebuah proporsi diri yang terhubung dengan tindakan yang akan datang.

\section{Structural Equation Modelling (SEM)}

Ghozali \& Fuad (2008) menjelaskan Structural Equation Modelling (SEM) sebagai evolusi dari model persamaan ganda yang berkembang dari prinsip ekonometri serta digabungkan dengan prinsip pengaturan ilmu psikologi dan sosiologi, lahir sebagai bagian integral dari penelitian akademis manajerial. Ada dua bagian SEM, yakni model variabel laten serta model pengukuran. Model variabel laten mengadaptasi model persamaan simultan pada ekonometri. Model pengukuran menggambarkan beberapa indikator atau variabel terukur sebagai efek atau refleksi dari variabel latennya.

\section{METODE PENELITIAN}

Penelitian ini menggunakan praktik observasi dan penyebaran angket. Populasi dari penelitian ini adalah semua pelanggan dari e-commerce Blibli. Penelitian ini menerapkan teknik purposive sampling dengan kriteria domisili di Jabodetabek dan menimal pernah melakukan transaksi pada e-commerce Blibli sebanyak dua kali. Tercatat ada total 200 responden yang terlibat dalam penelitian ini.

Angket yang digunakan berisikan pertanyaan-pertanyaan yang dirancang berdasarkan definisi operasional variabel e-service quality, persepsi nilai, kepuasan pelanggan, kepercayaan, serta niat perilaku. Beberapa keunggulan dari skala Likert adalah sederhana dan mudah dipahami oleh responden. Menurut Ghozali \& Kusumadewi (2013), skala Likert merupakan skala ordinal, namun dapat juga dianggap skala interval sehingga tidak perlu melakukan transformasi. Skala Likert dimulai dengan peringkat 1 yang memiliki pengertian "Sangat Tidak Setuju" sampai peringkat 5 sebagai "Sangat Setuju".

Menurut Roscoe dalam Sugiyono (2011), menyatakan ukuran sampel untuk penelitian yang dianggap layak ada dalam kisaran 30 hingga 500 sampel. Sehingga kuesioner akan disebarkan kepada 30 responden terlebih dahulu untuk diuji validitas dan reabilitasnya menggunakan software SPSS. Setelah valid dan reliabel, maka kuesioner akan disebarkan kepada 200 responden. Hasil dari pengumpulan data 200 responden ini kemudian diolah menggunakan metode SEM. Berikut ini adalah desain dan gambar model penelitian:

\section{Hubungan Kualitas E-Service dengan Persepsi Nilai}

Lien et al. (2010) menyatakan bahwa kualitas e-service memberi dampak secara positif/langsung terhadap persepsi nilai. Berdasarkan pernyataan-pernyataan dari penelitian sebelumnya di atas, maka dapat diajukan hipotesis sebagai berikut: 
$\mathrm{H}_{0} 1 \quad$ : kualitas $e$-service tidak memberi pengaruh yang signifikan terhadap persepsi nilai pada Blibli.com.

H1 : kualitas e-service memberi pengaruh yang signifikan terhadap persepsi nilai pada Blibli.com.

\section{Hubungan Kualitas E-Service dengan Kepuasan Pelanggan}

Akbar \& Djatmiko (2016) dalam penelitiannya mengatakan kualitas e-service memberi pengaruh yang positif dan signifikan pada kepuasan pelanggan. Lien et al. (2010) menyatakan bahwa kualitas e-service memberi dampak secara positif/langsung terhadap kepuasan pelanggan. Berdasarkan pernyataan-pernyataan dari penelitian sebelumnya di atas, maka dapat diajukan hipotesis sebagai berikut:

$\mathrm{H}_{0} 2$ : kualitas e-service tidak memberi pengaruh yang signifikan terhadap kepuasan pelanggan pada Blibli.com.

H2 : kualitas e-service memberi pengaruh yang signifikan terhadap kepuasan pelanggan pada Blibli.com.

\section{Hubungan Persepsi Nilai dengan Kepuasan Pelanggan}

Ardhi (2013) dalam penelitiannya menyatakan nilai persepsi membawa pengaruh yang positif pada kepuasan pelanggan. Lalu, Bernarto \& Patricia (2017) juga mengatakan persepsi nilai berpengaruh pada kepuasan pelanggan secara positif. Berdasarkan pernyataan-pernyataan dari penelitian sebelumnya di atas, maka dapat diajukan hipotesis sebagai berikut:

$\mathrm{H}_{0} 3$ : persepsi nilai tidak memberi pengaruh yang signifikan terhadap kepuasan pelanggan pada Blibli.com.

H3 : persepsi nilai memberi pengaruh yang signifikan terhadap kepuasan pelanggan pada Blibli.com.

\section{Hubungan Kualitas E-Service dengan Trust}

Dari hasil penelitian Ghalandari \& Branch (2012), dinyatakan bahwa kualitas e-service membawa pengaruh positif pada trust. Ting (2016) juga menyatakan kualitas $e$-service berefek kuat secara positif pada trust. Berdasarkan pernyataan-pernyataan dari penelitian sebelumnya di atas, maka dapat diajukan hipotesis sebagai berikut:

$\mathrm{H}_{0} 4$ : kualitas e-service tidak memberi pengaruh yang signifikan terhadap trust pada Blibli.com.

H4 : kualitas e-service memberi pengaruh yang signifikan terhadap trust pada Blibli.com.

\section{Hubungan Persepsi Nilai dengan Trust}

Menurut Suratman (2011) mengatakan bahwa terdapat pengaruh positif dari persepsi nilai terhadap trust. Sehingga, dari pernyataan tersebut dapat kita ajukan hipotesis sebagai berikut:

$\mathrm{H}_{0} 5$ : kualitas persepsi nilai tidak memberi pengaruh yang signifikan terhadap trust pada Blibli.com.

H5 : kualitas persepsi nilai memberi pengaruh yang signifikan terhadap trust pada Blibli.com. 


\section{Hubungan Kepuasan Pelanggan dengan Trust}

Dari hasil penelitian Bernarto \& Patricia (2017) ditemukan bahwa adanya pengaruh positif dari kepuasan pelanggan pada trust. Dalam penelitiannya, Semuel (2009) menuturkan kepuasan pelanggan membawa pengaruh positif pada kepercayaan/trust. Berdasarkan pernyataanpernyataan dari penelitian sebelumnya di atas, maka dapat diajukan hipotesis sebagai berikut: $\mathrm{H}_{0} 6$ : kepuasan pelanggan tidak memberi pengaruh yang signifikan terhadap trust pada Blibli.com.

H6 : kepuasan pelanggan memberi pengaruh yang signifikan terhadap trust pada Blibli.com.

\section{Hubungan Kualitas E-Service dengan Niat Perilaku}

Dari penelitiannya, Zeglat et al. (2016) mengatakan bahwa kualitas e-service mempunyai hubungan signifikan pada niat perilaku. Sehingga, dari pernyataan tersebut dapat kita ajukan hipotesis sebagai berikut:

$\mathrm{H}_{0} 7$ : kualitas e-service tidak memberi pengaruh yang signifikan terhadap niat perilaku pada Blibli.com.

H7 : kualitas e-service memberi pengaruh yang signifikan terhadap niat perilaku pada Blibli.com.

\section{Hubungan Nilai Persepsi dengan Niat Perilaku}

Menurut Setyawan (2010) mengatakan bahwa adanya pengaruh yang positif persepsi nilai pada niat perilaku. Sehingga, dari pernyataan tersebut dapat kita ajukan hipotesis sebagai berikut:

$\mathrm{H}_{0} 8$ : persepsi nilai tidak memberi pengaruh yang signifikan terhadap niat perilaku pada Blibli.com.

H8 : persepsi nilai memberi pengaruh yang signifikan terhadap niat perilaku pada Blibli.com.

\section{Hubungan Trust dengan Niat Perilaku}

Dari hasil penelitiannya, Taslim (2015) mengatakan bahwa trust memiliki pengaruh positif pada niat perilaku. Berdasarkan pernyataan dari penelitian sebelumnya di atas, maka dapat diajukan hipotesis sebagai berikut:

$\mathrm{H}_{0} 9$ : trust tidak memberi pengaruh yang signifikan terhadap niat perilaku pada Blibli.com. H9 : trust memberi pengaruh yang signifikan terhadap niat perilaku pada Blibli.com. 


\section{Gambar 1. Model Penelitian}

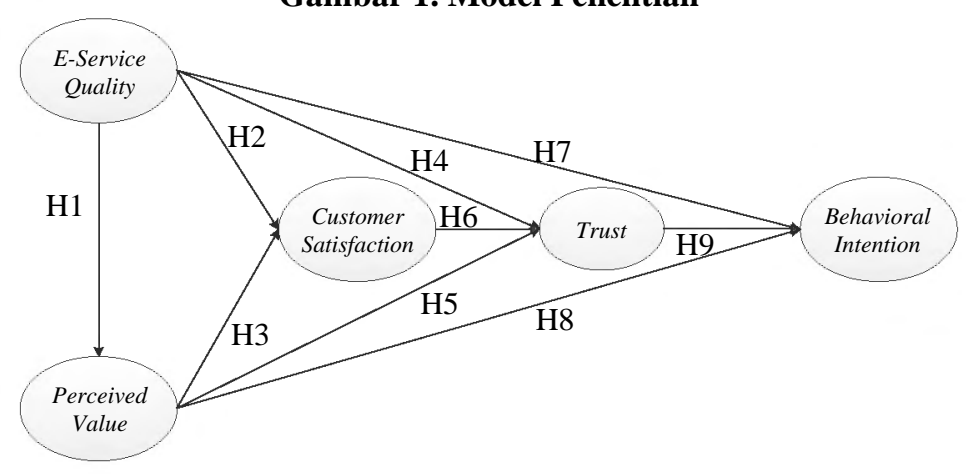

\section{HASIL DAN PEMBAHASAN}

Hasil daripada pengolahan data metode SEM menggunakan software LISREL adalah sebagai berikut:

\section{Gambar 2. Path diagram modifikasi 2 (Standardized)}

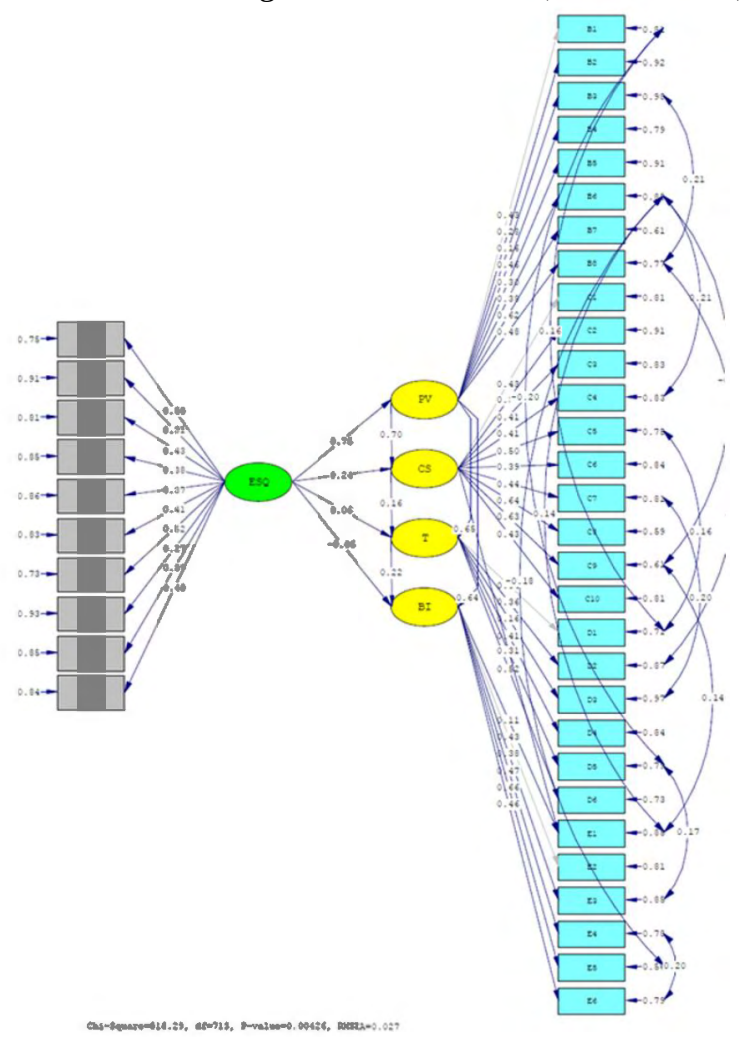




\section{Gambar 3. Path diagram modifikasi 2 (t-value)}

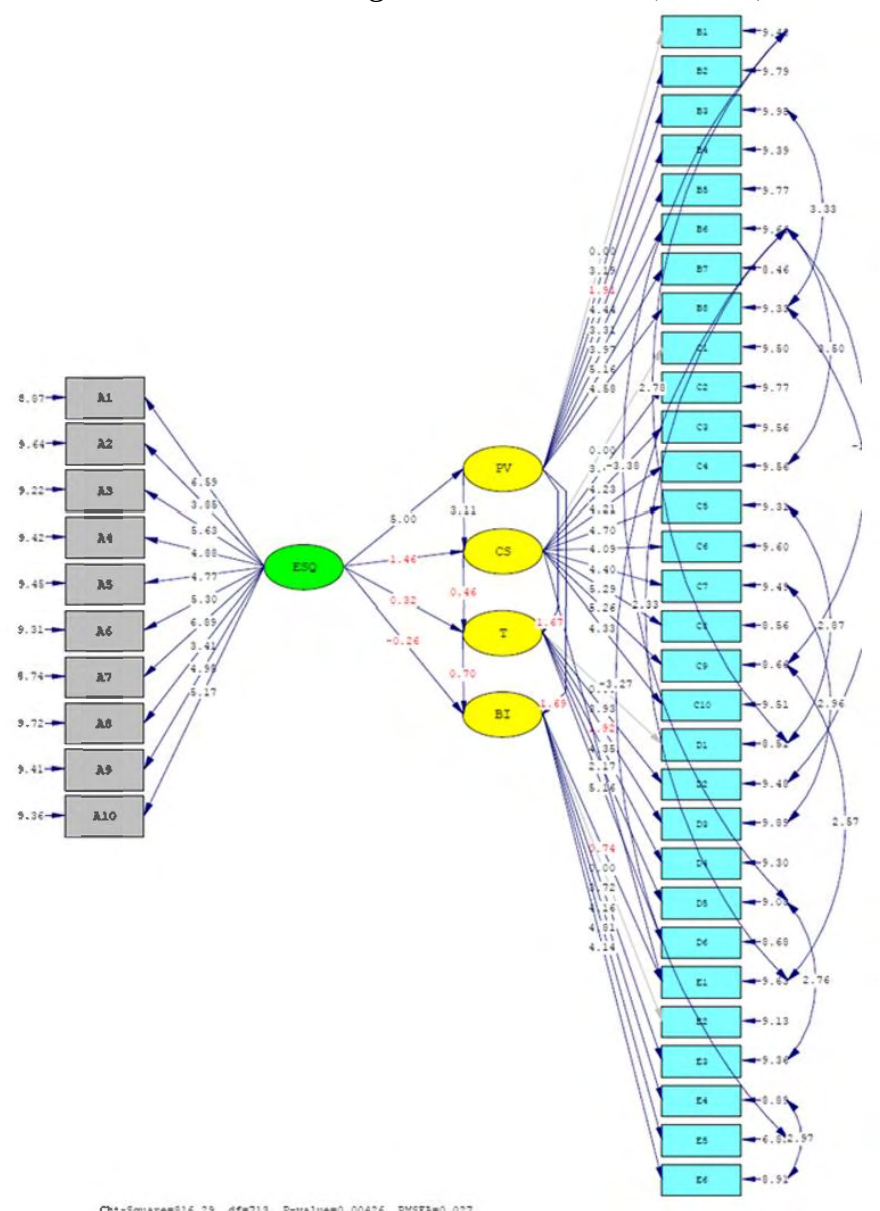

Gambar 4. Hasil Lisrel modifikasi 2

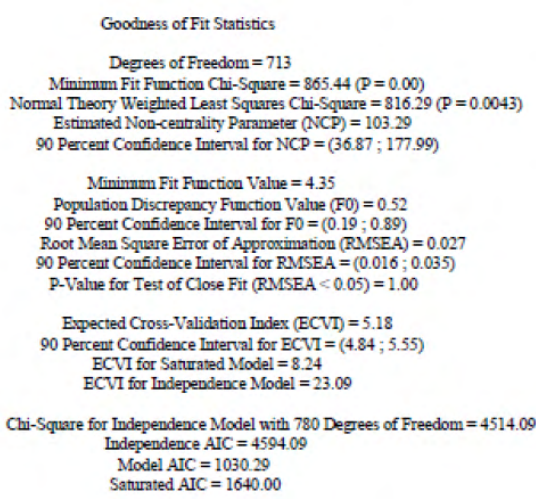

\section{Independence CAIC $=4766.03$}

Model CAIC $=1490.21$

Saturated CAIC $=5164.62$

Normed Fit Index $(\mathrm{NFF})=0.81$

Non-Normad Fit Index $(\mathrm{NNFI})=0.96$

Parsimony Nonmed Fit Index (PNFI) $=0.74$
Comparative Fit Index (CFI) $=0.96$

licremental Fit Index $(\mathrm{IFI})=0.96$
Relative Fit Index $(\mathrm{RFF})=0.79$

Critical $\mathrm{N}(\mathrm{CN})=185.82$

Root Mean Square Resictual (RMR) $=0.017$ Standardized RMR $=0.060$

Goodness of Fit Index (GFI) $=0.83$

Adjusted Goodness of Fit Index (AGFI) $=0.80$ Parsimoun Goodness of Fit Index (PGFI) $=0.72$ 


\section{Analisis Karakteristik Responden}

\section{Gender}

\section{Gambar 5. Persentase Gender Responden}

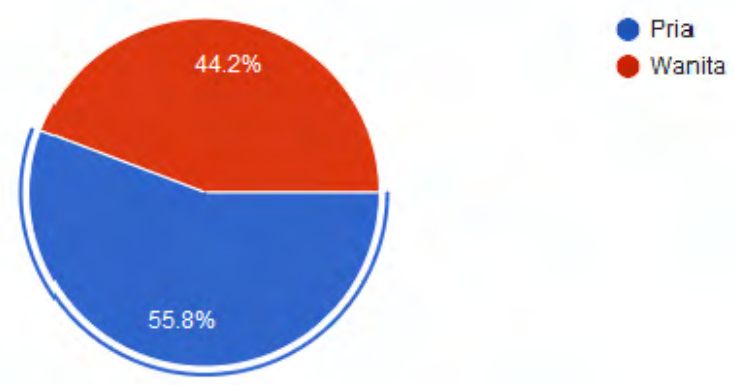

Berdasarkan grafik, didapatkan bahwa sebanyak 92 responden (44.2\%) merupakan wanita dan 116 responden (55.8\%) merupakan pria. Hal ini didukung dengan hasil survei yang didapatkan oleh APJII tahun 2017, bahwa sebesar 51.43\% pengguna intenet berjenis kelamin laki-laki dan $48.57 \%$ pengguna internet berjenis kelamin perempuan.

\section{Usia}

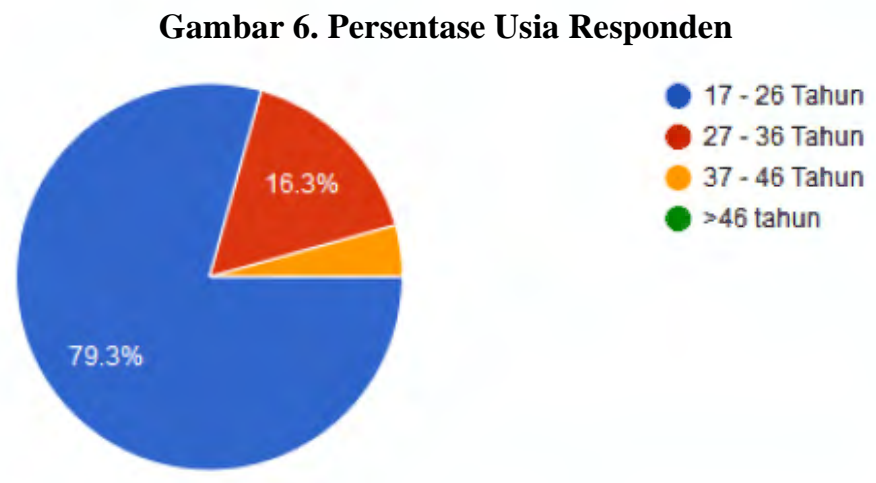

Berdasarkan grafik diatas, didapatkan bahwa sebanyak 165 responden $(79.33 \%)$ berusia 17-26 tahun, 34 responden (16.35\%) berusia 27-36 tahun, 9 responden $(4.32 \%)$ berusia 37-46 tahun, dan tidak ada responden yang berusia $>46$ tahun. Hal ini didukung dengan hasil survei yang didapatkan oleh APJII, dimana pengguna internet terbanyak (49.52\%) berada pada usia 19-34 tahun.

\section{Frekuensi Transaksi Responden dalam Setahun Terakhir}

Gambar 7. Persentase Transaksi Responden dalam Setahun Terakhir

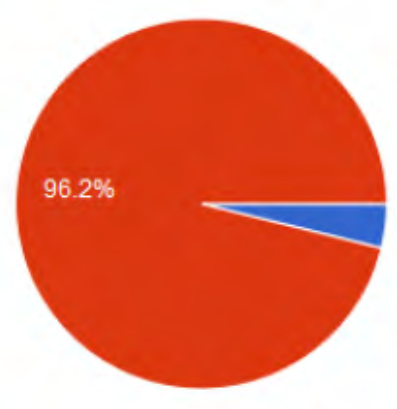

$<2$ kali dalam setahun terakhir

$>=2$ kali dalam setahun terakhir 
Berdasarkan grafik diatas, didapatkan bahwa sebanyak 200 responden (96.2\%) melakukan pembelian $\geq 2$ kali dalam setahun terakhir dan 8 responden (3.8\%) melakukan pembelian $<2$ kali dalam setahun terakhir. Data responden yang digunakan adalah responden yang melakukan pembelian $\geq 2$ kali dalam setahun terakhir (200 responden) dikarenakan perilaku pembelian responden ini telah menunjukkan adanya kepercayaan dan niat pembelian terhadap ecommerce Blibli.com.

\section{Analisis Uji Kecocokan Model Keseluruhan}

Tabel 1. Rekapitulasi Hasil Uji Kecocokan Model Keseluruhan

\begin{tabular}{|c|c|c|c|c|}
\hline No & $\begin{array}{c}\text { Kriteria } \\
\text { GOF }\end{array}$ & Parameter & Hasil software & Keterangan \\
\hline 1 & Chi square & Nilai yang kecil & 865,44 & tidak fit \\
\hline 2 & $p$-value & $\geq 0,05$ & 0 & tidak fit \\
\hline 3 & $\mathrm{NCP}$ & Nilai yang kecil & 103,29 & tidak fit \\
\hline 4 & RMSEA & $\leq 0.08$ & 0,027 & fit \\
\hline 5 & p-value & $\geq 0,05$ & 1 & fit \\
\hline 6 & ECVI & $\begin{array}{l}\text { ECVI < saturated } \\
<\text { independence }\end{array}$ & $\begin{array}{c}5,18(\mathrm{ECVI})<8,24 \text { (saturated })< \\
23,09(\text { independence })\end{array}$ & fit \\
\hline 7 & AIC & $\begin{array}{c}\mathrm{AIC}<\text { saturated }< \\
\text { independence }\end{array}$ & $\begin{array}{c}1030,29(\mathrm{AIC})<8,24 \text { (saturated) } \\
<23,09 \text { (independence) }\end{array}$ & fit \\
\hline 8 & CAIC & $\begin{array}{l}\text { CAIC < saturated } \\
<\text { independence }\end{array}$ & $\begin{array}{c}5,18(\mathrm{ECVI})<8,24 \text { (saturated })< \\
23,09(\text { independence })\end{array}$ & marginal fit \\
\hline 9 & NFI & $\geq 0,8$ & 0,81 & fit \\
\hline 10 & NNFI & $\geq 0,9$ & 0,96 & fit \\
\hline 11 & CFI & $\geq 0,9$ & 0,96 & fit \\
\hline 12 & IFI & $\geq 0,9$ & 0,96 & fit \\
\hline 13 & RFI & $\geq 0,8$ & 0,79 & tidak fit \\
\hline 14 & $\mathrm{CN}$ & $\geq 200$ & 185,82 & tidak fit \\
\hline 15 & $\begin{array}{c}\text { Standardized } \\
\text { RMR }\end{array}$ & $0,05 \leq \mathrm{RMRS} \leq 0,08$ & 0,06 & marginal fit \\
\hline 16 & GFI & $0,8 \leq \mathrm{RMRS} \leq 0,9$ & 0,83 & marginal fit \\
\hline 17 & AGFI & $\geq 0,8$ & 0,8 & fit \\
\hline
\end{tabular}

Berdasarkan tabel diatas, didapatkan bahwa terdapat 5 dari 17 parameter yang tidak fit, atau sekitar $71 \%$ kecocokan daripada model penelitian ini. Menurut Ghozali \& Fuad (2005) menyatakan bahwa apabila hasil yand ditunjukkan sebagian besar ukuran GOF baik, maka dapat diambil kesimpulan bahwa model adalah baik karena model telah menggambarkan kondisi aktualnya. Menurut Wijanto (2008) menyatakan bahwa dalam hal ukuran kecocokan keseluruhan, tidak ada satuan GOF yang secara eksklusif bisa mewakili kecocokan keseluruhan model, peneliti padaa umumnya akan menghentikan perbaikan kecocokan keseluruhan model, setelah banyak ukuran GOF menampilkan hasil kecocokan keseluruhan model yang baik. 
Berdasarkan hal tersebut, model penelitian yang telah dibuat ini sudah baik, dikarenakan sebagian besar parameter sudah menunjukkan kecocokan yang baik (71\% fit).

\section{Analisis Uji Kecocokan Measurements Model}

Tabel 2. Rekapitulasi Hasil Uji Kecocokan Measurement Model

\begin{tabular}{|c|c|c|c|c|}
\hline Variabel Laten & Kriteria & Parameter & Hasil & Keterangan \\
\hline \multirow{2}{*}{ Kualitas e-service } & $\mathrm{CR}$ & $\geq 0,5$ & 0,65 & reliabel \\
\cline { 2 - 5 } & $\mathrm{VE}$ & $\geq 0,5$ & 0,163 & tidak reliabel \\
\hline \multirow{2}{*}{ Persepsi nilai } & $\mathrm{CR}$ & $\geq 0,5$ & 0,592 & reliabel \\
\cline { 2 - 5 } & $\mathrm{VE}$ & $\geq 0,5$ & 0,168 & tidak reliabel \\
\hline \multirow{2}{*}{$\begin{array}{c}\text { Kepuasan } \\
\text { Pelanggan }\end{array}$} & $\mathrm{CR}$ & $\geq 0,5$ & 0,68 & reliabel \\
\cline { 2 - 5 } & $\mathrm{VE}$ & $\geq 0,5$ & 0,175 & tidak reliabel \\
\hline \multirow{2}{*}{ Trust } & $\mathrm{CR}$ & $\geq 0,5$ & 0,52 & reliabel \\
\cline { 2 - 5 } & $\mathrm{VE}$ & $\geq 0,5$ & 0,165 & tidak reliabel \\
\hline \multirow{2}{*}{ Niat Perilaku } & $\mathrm{CR}$ & $\geq 0,5$ & 0,57 & reliabel \\
\cline { 2 - 5 } & $\mathrm{VE}$ & $\geq 0,5$ & 0,201 & tidak reliabel \\
\hline
\end{tabular}

Berdasarkan hasil rekapitulasi diatas, ditunjukkan bahwa nilai construct reliability pada setiap variabel laten sudah baik karena telah memenuhi parameter yang ada, sedangkan nilai variance extracted semua variabel masih belum baik karena masih belum memenuhi parameter yang ada. Menurut Hair et al. (1998) menyatakan bahwa nilai variance extracted merupakan optional atau tidak diharuskan. Berdasarkan hal tersebut, maka ukuran reliabilitas yang digunakan dalam penelitian ini hanya nilai construct reliability. Kesimpulannya, semua variabel laten dalam penelitian ini sudah reliabel.

\section{Analisis Hipotesis Penelitian}

Berdasarkan model penelitian yang ada, terdapat 9 hipotesis penelitian. Hipotesis tersebut diuji dengan membandingkan hasil nilai $t$-value yang didapatkan dari software LISREL dengan nilai tabel distribusi t. Tingkat signifikansi yang digunakan sebesar 5\% $=0.05$, dengan $\mathrm{df}=$ $200($ responden $)-5($ variabel $)=195$ maka didapatkan nilai t tabel sebesar 1.9722 . Berikut ini merupakan rekapitulasi hasil uji hipotesis yang telah dilakukan. 
Tabel 3. Rekapitulasi Hasil Uji Hipotesis Penelitian

\begin{tabular}{|c|l|c|c|c|}
\hline No & \multicolumn{1}{|c|}{ Pengaruh } & t-value & Parameter & Keterangan \\
\hline 1 & $\begin{array}{l}\text { Pengaruh kualitas } \text { e-service terhadap nilai } \\
\text { persepsi }\end{array}$ & 5,00 & 1,9722 & Tolak H01 \\
\hline 2 & $\begin{array}{l}\text { Pengaruh kualitas } \text { e-service terhadap kepuasan } \\
\text { pelanggan }\end{array}$ & 1,46 & 1,9722 & Terima H02 \\
\hline 3 & $\begin{array}{l}\text { Pengaruh nilai persepsi terhadap kepuasan } \\
\text { pelanggan }\end{array}$ & 3.11 & 1,9722 & Tolak H03 \\
\hline 4 & Pengaruh kualitas e-service terhadap trust & 0.32 & 1,9722 & Terima H04 \\
\hline 5 & Pengaruh nilai persepsi terhadap trust & 1.67 & 1,9722 & Terima H05 \\
\hline 6 & Pengaruh kepuasan pelanggan terhadap trust & 0.46 & 1,9722 & Terima H06 \\
\hline 7 & $\begin{array}{l}\text { Pengaruh kualitas } e \text {-service terhadap niat } \\
\text { perilaku }\end{array}$ & -0.26 & 1,9722 & Terima H07 \\
\hline 8 & $\begin{array}{l}\text { Pengaruh nilai persepsi value terhadap niat } \\
\text { perilaku }\end{array}$ & 1.69 & 1,9722 & Terima H08 \\
\hline 9 & Pengaruh trust terhadap niat perilaku & 0.7 & 1,9722 & Terima H09 \\
\hline
\end{tabular}

Berdasarkan hasil yang didapat, nilai t-value (5.00) > t tabel menyatakan bahwa adanya pengaruh positif yang dimiliki kualitas e-service yang signifikan terhadap nilai persepsi pada blibli.com. Hal ini sesuai dengan hasil dari penelitian Barus (2013) yang mengatakan kualitas $e$-service berkontribusi pada persepsi nilai secara signifikan. Selain itu, hasil penelitian yang dilakukan Bei \& Chiao (2001) menyatakan bahwa kualitas $e$-service memberi dampak secara positif/langsung terhadap persepsi nilai. Teori tersebut didukung dengan pelayanan customer yang diterapkan di e-commerce Blibli. E-service yang diberikan oleh Blibli kepada customer adalah fitur live chat dan customer care $24 \times 7$ (telepon dan email). Pada fitur live chat ini, customer care Blibli akan membantu calon customer dalam melakukan transaksi secara online, dan customer care $24 \times 7$ akan mempermudah customer untuk melakukan pengaduan/klaim produk yang mereka beli.

Berdasarkan hasil yang didapat, nilai $t$-value $(1.46)<\mathrm{t}$ tabel menyatakan bahwa tidak adanya pengaruh positif yang secara signifikan dimiliki oleh kualitas e-service terhadap kepuasan pelanggan pada Blibli.com. Menurut Wilson et al. (2012), kepuasan pelanggan atau konsumen dapat diciptakan melalui kualitas produk dan pelayanan konsumen. Berdasarkan hal tersebut, kualitas produk memiliki peranan yang lebih besar dalam customer satisfaction customer blibli, artinya masih banyak customer yang belum yakin dengan kualitas produk yang dijual oleh blibli. Hal tersebut dapat disebabkan oleh masih terdapat review produk yang kurang baik ataupun terdapat infomasi-informasi produk yang belum lengkap dituliskan pada kolom deskripsi produk.

Berdasarkan hasil yang didapat, nilai $t$-value (3.11) $>\mathrm{t}$ tabel menyatakan bahwa persepsi nilai secara signifikan memiliki pengaruh positif pada kepuasan pelanggan pada Blibli.com. Hal ini sesuai dengan hasil penelitian yang telah dijalankan oleh Ardhi (2013) yang menyatakan bahwa 
persepsi nilai memberikan pengaruh positif terhadap kepuasan pelanggan. Selain itu, hasil dari penelitian Bernarto \& Patricia (2017) menyatakan bahwa persepsi nilai berpengaruh positif terhadap kepuasan pelanggan. Teori tersebut menyatakan bahwa customer dari e-commerce melakukan penilaian tentang produk dan merchant berdasarkan deskripsi produk dan review dari customer-customer yang sudah pernah melakukan transaksi sebelumnya. Berdasarkan review tersebut, customer sudah mendapatkan gambaran produk/pelayanan yang akan mereka terima pada saat melakukan transaksi.

Berdasarkan hasil yang didapat, nilai $t$-value $(0.32)<\mathrm{t}$ tabel menyatakan bahwa tidak adanya pengaruh signifikan yang dimiliki kualitas e-service terhadap trust pada Blibli.com. Hal ini juga didukung dengan hasil dari penelitian Annisa (2016) menyatakan bahwa tidak ditemukan hubungan antara variabel kualitas e-service terhadap tingkat kepercayaan pelanggan (trust). Teori dan hasil penelitian ini menunjukkan bahwa variabel e-service quality tidak termasuk salah satu faktor utama yang mempengaruh trust pada blibli.com. Menurut Fogg \& Tseng (1999), menyatakan bahwa seseorang akan merasa yakin (trust) dengan sesuatu akan ditunjukkan dengan adanya perasan positif yang berupa reliability, dependability, dan confidence. Berdasarkan hal tersebut, customer care yang diberikan oleh Blibli sekarang belum dapat menunjukkan reliability, dependability, dan confidence. Hal ini dapat dipengaruhi oleh waktu penyampaian informasi yang relatif lama (email) dan biaya customer care yang cukup besar (telepon). Penyampaian informasi yang cukup lama tersebut juga dipengaruhi oleh lokasi stok produk, dimana Blibli tidak melakukan pengadaan stok untuk sebagian besar barang yang dijual. Sehingga terdapat beberapa tahapan untuk mendapatkan informasi yang diinginkan oleh customer, contohnya mengecek keadaan stok produk ke merchant.

Berdasarkan hasil yang didapat, nilai $t$-value $(1.67)<\mathrm{t}$ tabel menyatakan bahwa tidak adanya pengaruh signifikan yang dimiliki oleh nilai persepsi terhadap trust pada Blibli.com. Menurut Ardyanto (2015), kepercayaan konsumen dipengaruhi oleh kemudahan konsumen dalam mengakses e-commerce. Hal ini dapat disebabkan oleh terdapat beberapa informasi-informasi yang tidak lengkap pada page Blibli. Seperti kurangnya deskripsi produk dan informasi terkait merchant, contohnya sudah seberapa lama merchant tersebut bergabung bersama Blibli, review mengenai merchant, deskripsi produk). Hal tersebut menyebabkan customer sulit dalam melakukan transaksi, dimana customer harus mencari informasi sendiri mengenai produk dan merchant.

Berdasarkan hasil yang didapat, nilai t-value $(0.46)<\mathrm{t}$ tabel menunjukkan tidak adanya pengaruh signifikan yang dimiliki kepuasan pelanggan terhadap trust pada Blibli.com. Hal tersebut juga didukung dengan penelitian Annisa (2016) menyatakan bahwa tidak ditemukan hubungan antara variabel kepuasan pelanggan terhadap trust customer. Trust akan muncul pada customer jika kegiatan transaksi ini terjadi sesuai dengan ekspektasi customer. Menurut Wilson et al. (2012), kepuasan konsumen (customer satisfaction) dapat diciptakan melalui kualitas produk dan layanan konsumen. Artinya kualitas produk dan layanan konsumen yang disediakan oleh Blibli masih perlu ditingkatkan. 
Berdasarkan hasil yang didapat, nilai $t$-value $(-0.26)<\mathrm{t}$ tabel menunjukkan tidak adanya pengaruh signifikan yang dimiliki kualitas e-service terhadap niat perilaku pada Blibli.com. Hal ini sesuai dengan hasil dari penelitian Pratiwi \& Dewi (2016) yang menyatakan bahwa kualitas e-service tidak berpengaruh signifikan pada niat perilaku. Hal ini dapat disebabkan oleh belum munculnya trust pada pelanggan yang mana masih khawatir dengan risiko dari pembelian secara online. Rasa khawatir customer dapat diturunkan dengan adanya kualitas $e$ service yang baik, namun $e$-service yang diberikan oleh Blibli belum maksimal seperti lamanya penyampaian informasi (melalui email) dan mahalnya biaya hotline customer care (telepon) sehingga mengakibatkan turunnya niat transaksi dari customer.

Berdasarkan hasil yang didapat, nilai t-value $(1.69)<\mathrm{t}$ tabel menunjukkan tidak adanya pengaruh signifikan yang dimiliki nilai persepsi terhadap niat perilaku pada Blibli.com. Hal ini didukung pula oleh hasil penelitian Indrata et al. (2017) yang menunjukkan nilai perilaku tidak berpengaruh secara signifikan terhadap niat perilaku pelanggan. Hal ini dapat disebabkan oleh terdapat beberapa informasi-informasi yang tidak lengkap pada laman Blibli. Seperti kurangnya deskripsi produk dan informasi terkait merchant, misalnya sudah seberapa lama merchant tersebut join bersama Blibli, review mengenai merchant. Hal tersebut menyebabkan customer menjadi ragu dalam melakukan transaksi.

Berdasarkan hasil yang didapat, nilai $t$-value $(0.7)<\mathrm{t}$ tabel menunjukkan tidak adanya pengaruh signifikan yang dimiliki trust terhadap niat perilaku pada Blibli.com. Hasil ini didukung oleh hasil penelitian Shomad \& Purnomoshidi (2013) yang menuturkan bahwa adanya pengaruh signifikan yang dimiliki trust pada niat perilaku e-commerce. Ketidaksesuaian hasil penelitian ini dapat disebabkan oleh banyaknya masyarakat yang sudah memiliki pengalaman dalam menggunakan e-commerce. Menurut Kaplan \& Saddock (2007), kecemasan merupakan respon akan situasi tertentu yang mengancam, dan merupakan normal terjadi menyertai perkembangan, perubahan, pengalaman baru atau yang belum pernah dialami, serta dalam menemukan identitas diri dan arti hidup. Hal ini didukung dengan hasil penelitian Tan \& Waheed (2011) yang mengatakan tidak adanya pengaruh signifikan yang trust miliki terhadap niat perilaku dengan responden dalam penelitian tersebut merupakan pengguna $G$-market yang telah mengetahui bagaimana penggunaan $e$-commerce.

\section{Implikasi Manajerial}

Beberapa variabel yang memiliki pengaruh positif secara signifikan adalah variabel $e$-service quality dan perceived value. Selanjutnya dilakukan perhitungan rata-rata dari construct reliability (CR) yang juga mewakili seberapa besar pengaruh dari tiap indikator terhadap variabel laten. Indikator yang memiliki nilai $\mathrm{CR}$ dibawah rata-rata merupakan indikatorindikator yang perlu ditingkatkan. Berikut ini adalah rekapitulasi CR variabel kualitas e-service dan persepsi nilai. 
Tabel 4. Rekapitulasi CR Variabel Kualitas E-Service dan Persepsi Nilai

\begin{tabular}{|c|c|c|c|c|c|}
\hline Indikator & ESQ & CR & Indikator & PV & CR \\
\hline \multirow{2}{*}{$\begin{array}{c}\text { Information } \\
\text { Quality }\end{array}$} & 0,5 & \multirow{2}{*}{0,405} & \multirow{2}{*}{ Nilai Emosional } & 0,43 & \multirow{2}{*}{0,355} \\
\hline & 0,31 & & & 0,28 & \\
\hline \multirow{2}{*}{ Security } & 0,43 & \multirow{2}{*}{0,405} & \multirow{2}{*}{ Nilai Sosial } & 0,16 & \multirow{2}{*}{0,31} \\
\hline & 0,38 & & & 0,46 & \\
\hline \multirow{2}{*}{$\begin{array}{c}\text { Website } \\
\text { Functionality }\end{array}$} & 0,37 & \multirow{2}{*}{0,39} & \multirow{2}{*}{$\begin{array}{c}\text { Nilai Fungsional } \\
\text { Harga }\end{array}$} & 0,3 & \multirow{2}{*}{0,34} \\
\hline & 0,41 & & & 0,38 & \\
\hline \multirow{2}{*}{$\begin{array}{c}\text { Customer } \\
\text { Relationship }\end{array}$} & 0,52 & \multirow{2}{*}{0,395} & \multirow{2}{*}{$\begin{array}{c}\text { Nilai Fungsional } \\
\text { Kualitas }\end{array}$} & 0,62 & \multirow{2}{*}{0,55} \\
\hline & 0,27 & & & 0,48 & \\
\hline \multirow{2}{*}{$\begin{array}{l}\text { Responsiveness } \\
\text { and Fullfillment }\end{array}$} & 0,39 & \multirow{2}{*}{0,395} & & & \multirow[b]{3}{*}{875} \\
\hline & 0,4 & & & & \\
\hline Rata-Rata & \multicolumn{2}{|c|}{0,398} & & & \\
\hline
\end{tabular}

Berdasarkan tabel diatas, diperlukan peningkatan pada indikator website functionality, customer relationship, dan responsiveness and fullfillment pada variabel kualitas e-service quality dan nilai emosional, nilai sosial, dan nilai fungsional harga pada variabel persepsi nilai.

Variabel persepsi nilai ini dapat ditingkatkan dengan cara meningkatkan nilai emosional, nilai sosial, dan nilai fungsional harga dari e-commerce Blibli. Pada bagian nilai emosional ini, pihak Blibli dapat menambahkan foto asli dari produk yang dijual bukan hanya gambar dari produk katalog. Customer akan memiliki gambaran yang lebih jelas jika diberikan foto asli dari penggunaan produk yang dijual sehingga customer dapat merasa yakin dalam melakukan transaksi produk tersebut.

Pada bagian nilai sosial ini, pihak Blibli dapat menambahkan informasi-informasi penting yang dapat meyakinkan customer untuk melakukan pembelian di e-commerce Blibli. Informasi tersebut terdiri dari informasi barang yang dijual dan informasi merchant/penjual. Informasi barang yang dijual ini sudah cukup meyakinkan dimana Blibli sudah mencantumkan informasiinformasi yang lengkap, seperti: harga, point rewards, pilihan cicilan, stok barang, fitur produk, garansi produk, spesifikasi, dan review dari customer yang pernah melakukan pembelian produk tersebut.

Dilain hal pada bagian user interface merchant/penjual, dimana hanya sedikit informasi yang ditampilkan oleh pihak Blilbi. Blibli.com sudah memberikan skala penilaian mengenai kecepatan merespon pesanan, ketersediaan produk, dan kualitas produk yang dijual, namun masih terdapat kekurangan pada bagian informasi merchant dimana hanya sedikit sekali keterangan mengenai toko yang menjual barang-barangnya di Blilbi.com. E-commerce Blibli.com dapat menambahkan informasi-informasi penting mengenai toko-toko yang membuka lapak di Blibli.com, seperti menambahkan informasi tentang sudah berapa toko tersebut membuka lapak di Blibli.com, seberapa banyak barang yang sudah dijual oleh toko tersebut, dan informasi hasil review Blibli.com sendiri mengenai toko tersebut. Pada bagian informasi toko, hanya terdapat ulasan yang disampaikan oleh konsumen yang pernah 
berbelanja di toko tersebut dan juga tidak dilampirkan seberapa banyak konsumen yang melakukan penilaian.

E-commerce Blibli dapat memberikan informasi yang rinci mengenai toko-toko yang melakukan penjualan di Blibli. Dengan lengkapnya informasi yang diberikan, maka akan semakin mudah perusahaan dalam melakukan pelayanan pelanggannya, dimana informasiinformasi penting yang dibutuhkan oleh konsumen sudah tersedia, dan perusahaan juga dapat memfokuskan pelayanan pada bagian lainnya, seperti feedback dan panduan lainnya.

Pada bagian nilai fungsional harga, pihak Blibli sulit untuk bersaing harga, dimana konsep daripada Blibli adalah online shopping mall yang artinya barang yang dijual Blibli sudah memiliki merek tersendiri. Salah satu cara Blibli untuk dapat menarik customer adalah dengan mengadakan flash sale, dimana flash sale ini dilakukan pada jam dan durasi tertentu dan pada sejumlah barang dan kuantitas tertentu. Pengadaan flash sale ini akan dapat meningkatkan jumlah pengunjung e-commerce. Selain variabel persepsi nilai, e-commerce Blibli juga dapat meningkatkan kualitas e-service yang ada. Peningkatan kualitas e-service dapat dimulai dengan peningkatan pada indikator website functionality, customer relationship, dan responsiveness and fullfillment.

Pada bagian website functionality, pihak Blibli sudah cukup memberikan kesan yang menarik pada bagian user interface dari website Blibli. Beberapa hal yang dapat ditampilkan untuk dapat memperkuat website functionality yaitu dengan menampilkan promo-promo yang akan datang, sehingga customer akan sering melakukan kunjungan ke website untuk melakukan pengecekan promo, menampilkan produk best seller sehingga customer menjadi tertarik untuk mencari informasi lanjutan terkait produk tersebut.

Pada bagian customer relationship dan responsiveness and fullfillment, pihak Blibli sudah menyediakan pelayanan customer yang cukup lengkap dimana terdapat bantuan customer service $24 \times 7$ (telepon/email), dan juga ada bantuan customer untuk melakukan kegiatan transaksi. Selain itu, e-commerce Blibli juga menyediakan informasi-informasi penting ke beberapa bagian, seperti cara pembayaran, pengiriman, pengembalian barang, dan panduan lainnya yang dapat customer baca pada saat mengunjungi website Blibli.com. Pada homepage Blibli ini, tersedia menu "perlu bantuan?" yang akan membuka tab livechat dengan customer care Blibli untuk membantu customer yang akan melakukan pembelian ataupun menanyakan informasi-informasi penting lainnya.

Pelayanan yang dapat dikembangkan oleh pihak e-commerce Blibli untuk meningkatkan kualitas e-service adalah dengan memberikan hotline gratis untuk para pelanggan Blibli. Hotline yang sekarang tersedia masih berbayar dan hal tersebut membuat para customer merasa keberatan untuk melakukan komplain tentang ketidaknyamanan/klaim dari produk yang mereka beli. Hal ini tersebut membuat customer merasa dirugikan dan Blibli berpotensi kehilangan pelanggannya. 


\section{SIMPULAN}

Berdasarkan hasil pengolahan data dan analisis yang telah dilakukan, didapatkan beberapa kesimpulan, yaitu kualitas e-service (E-service quality) memiliki pengaruh positif yang signifikan terhadap nilai persepsi (perceived value). E-service quality tidak memiliki pengaruh positif yang signifikan terhadap kepuasan pelanggan (customer satisfaction). Perceived value memiliki pengaruh positif yang signifikan terhadap customer satisfaction. E-service quality tidak memiliki pengaruh positif yang signifikan terhadap trust. Perceived value tidak memiliki pengaruh positif yang signifikan terhadap trust. Customer satisfaction tidak memiliki pengaruh positif yang signifikan terhadap trust. E-service quality tidak memiliki pengaruh negatif yang signifikan terhadap niat perilaku (behavioral intention). Perceived value tidak memiliki pengaruh positif yang signifikan terhadap behavioral intention. Trust tidak memiliki pengaruh positif yang signifikan terhadap behavioral intention.

\section{DAFTAR PUSTAKA}

Akbar, A. A., \& Djatmiko. (2016). Pengaruh E-Service Quality terhadap E-Customer Satisfaction dan E-Customer Loyalty pada Lazada.co.id. e-Proceeding of Management, $3(1), 142-150$.

Annisa. (2016). Analisis Pengaruh E-service Quality Terhadap E-Trust dan E-Satisfaction Serta Implikasinya Pada E-loyalty dan Positive E-WOM; Telaah Pada Konsumen Wanita bobobobo.com (No. Publikasi 122) [Skripsi Strata I, Universitas Multimedia Nusantara]. UMN Knowledge Center.

Ardhi, D.F.X. (2013). Pengaruh Customer Perceived Value, Customer Satisfaction dengan Moderasi Switching Cost terhadap Customer Loyalty dalam Online Shop Bhinneka.com. Ultima Management, 5(2), 35-45.

Ardyanto, D. (2015). Pengaruh Kemudahan Dan Kepercayaan Menggunakan. E-Commerce Terhadap Keputusan Pembelian Online (Survei Pada. Konsumen www. petersaysdenim. com). Jurnal Administrasi Bisnis, 22(1).

Ariyanto, H. H. (2003). Hubungan Karakteristik Konsumen dalam Evaluasi terhadap Brand Imitation. Elex Media Komputindo.

Bei, L., \& Chiao, Y. (2001). An Integrated Model for the Effects of Perceived Product, Perceived Service Quality, and Perceived Price Fairness on Consumer Satisfaction and Loyalty. Journal of Consumer Satisfaction, Dissatisfaction and Complaining Behavior, $14,125-141$.

Bernarto, I., \& Patricia. (2019). Pengaruh Perceived Value, Customer Satisfaction, dan Trust terhadap Customer Loyalty Restoran XYZ di Tangerang. Journal of Business Studies, $4(1), 36-49$. 
Fogg, B. J., \& Tseng, H. (1999). The elements of computer credibility. Proceedings of the SIGCHI Conference on Human factors in Computing Systems, 80-87. https://doi.org/10.1145/302979.303001

Ghalandari, K., \& Branch, N. (2012). The Effect of E-Service Quality on E-Trust and ESatisfaction as Key Factor Influencing Creation of E-Loyalty in E-Business Context: The Moderating Role of Situational Factors. Journal of Basic and Applied Scientific Research, 2(12), 12847-12855.

Ghozali, H. I. dan Fuad. (2005). Structural Equation Modeling: Teori, Konsep, dan Aplikasi Dengan Program LISREL 8.54. Badan Penerbit Universitas Diponegoro.

Ghozali, H. I. dan Fuad. (2008). Structural Equation Modeling: Teori, Konsep, dan Aplikasi Dengan Program LISREL 8.80 (2nd ed.). Badan Penerbit Universitas Diponegoro.

Ghozali, I., \& Kusumadewi, K. A. (2013). Teknik Penyusunan Skala Likert (Summated Scales) Dalam Penelitian Akuntansi dan Bisnis. Fatawa Publishing.

Hair, J. F., Anderson, R. E., Tatham, R. L., \& Black, W. C. (1998). Multivariate Data Analysis (5th ed.). Prentice Hall.

Hansen, D. R., \& Mowen M. M. (2012). Manajemen Biaya. Salemba Empat.

Ho, C. dan Lee Y. (2007). The Development of an E-Travel Service Quality Scale. Tourism Management, 28(6), 1434-1449. https://doi.org/10.1016/j.tourman.2006.12.002

Holbrook, M. (1994). The nature of customer value: an axiology of services in the consumption experience. In R. T. Rust \& R. L. Oliver (Eds.), Service quality: New directions in theory and practice (pp. 21-71). SAGE Publications, Inc. http://dx.doi.org/10.4135/9781452229102.n2

Indrata, S. L., Susanti, C. E., \& Kristanti, M. M. (2017). Pengaruh perceived value dan eservice quality terhadap customer behavioral intentions melalui customer satisfaction pada pengguna gojek di Surabaya. Kajian Ilmiah Mahasiswa Manajemen, 6(2), 131147.

Kaplan, H. I., \& Saddock, B. J. (2007). Sinopsis Psikiatri Ilmu pengetahuan Perilaku Psikiatri Klinis Jilid 1 (10th ed.). Bina Rupa Aksara.

Kotler, P. (2011). Manajemen Pemasaran di Indonesia: Analisis, Perencanaan, Implementasi dan Pengendalian. Salemba Empat. 
Lau, G. T., \& Lee, S. H. (1999). Consumers Trust in A Brand and Link to Brand Loyalty. Journal of Market-Focused Management, 4(4), 341-270. https://doi.org/10.1023/A:1009886520142

Lien, C., Wen M., \& Wu, C. (2011). Investigating the Relationships among E-Service Quality, Perceived Value, Satisfaction, and Behavioral Intentions in Taiwanese Online Shopping. Asia Pacific Management Review, 16(3), 211-223. http://dx.doi.org/10.6126/APMR.2011.16.3.01

Mayer, R.C., Davis, J. H., \& Schoorman, F. D. (1995). An Integrative Model of Organizational Trust. The Academy of Management Review, 20(3), 709-743. https://doi.org/10.2307/258792

Moorman, C., Deshpandé, R., \& Zaltman, G. (1993). Factors Affecting Trust in Market Research Relationships. Journal of Marketing, 57(1), 81-101. https://doi.org/10.1177/002224299305700106

Peter, P. J, \& Olson, J. C. (2008). Consumer Behavior perilaku konsumen dan strategi pemasaran. Erlangga.

Pratiwi, S. A., \& Dewi, C. K. (2016) Pengaruh E-Service Quality Terhadap Behavior Intentions Dengan E Satisfaction Sebagai Mediator (Studi Pada Kriya.co.id). Jurnal Computech \& Bisnis, 10(2), 59-71.

Santos, J. (2003). E-Service Quality: A Model of Virtual Service Dimensions. Managing Service Quality. Managing Service Quality: An International Journal, 13(3), 233-246. https://doi.org/10.1108/09604520310476490

Setyawan, B. (2010). Pengaruh Perceived Quality, Perceived Sacrifice, Perceived Value, Satisfaction pada Behavioral Intentions (survei pada mahasiswa Universitas Sebelas Maret Surakarta) (No. Publikasi 16490) [Skripsi Strata I, Universitas Sebelas Maret]. UPT Perpustakaan Universitas Sebelas Maret.

Shomad, A. C., \& Purnomosidhi, B. (2013). Pengaruh Kepercayaan, Persepsi Kegunaan, Persepsi Kemudahan, dan Persepsi Risiko Terhadap Perilaku Penggunaan ECommerce. Jurnal Ilmiah Mahasiswa FEB, 1(2).

Sugiyono. (2011). Statistika Untuk Penelitian. Alfabeta.

Suratman, A. (2011). Analisis Pengaruh Perceived Value, Kepuasan dan Kepercayaan Pada Loyalitas Konsumen (Studi Pada Pelanggan Transportasi Rosalia Indah, Karanganyar). Riset Manajemen dan Akuntansi STIE Atma Bhakti, 2(4). 
Syamsiah, N. (2009). Analisis Faktor-Faktor yang Mempengaruhi Nilai yang Dirasakan Pelanggan untuk Menciptakan Kepuasan Pelanggan di RSUP Dokter Kariadi Semarang (No. Publikasi 18365) [Tesis Magister, Universitas Diponegoro]. Diponegoro University | Institutional Repository (UNDIP-IR).

Tan, T. H., \& Waheed, A. (2011). Herzberg's Motivation-Hygiene Theory and Job Satisfaction in the Malaysian Retail Sector: The Mediating Effect of Love of Money. Asian Academy of Management Journal, 16(1), 73-94.

Taslim, K. (2015). Analisis Hubungan Antara E-Service Quality dan Trust pada Customer Satisfaction dan Behavioral Intentions Telaah pada Net Generation Konsumen Lazada Indonesia. $\quad$ Ultima $\quad$ Management. $\quad 7(1), \quad 62-82$. https://doi.org/10.31937/manajemen.v7i1.924

Ting, O. S., Ariff, M. S. M., Zakuan, N., Sulaiman, Z., \& Saman, M. Z. M. (2016). E-Service Quality, E-Satisfaction and E-Loyalty of Online Shoppers in Business to Consumer Market; Evidence form Malaysia. IOP Conference Series: Materials Science and Engineering, 131. http://doi.org/10.1088/1757-899X/131/1/012012

Wilson, A., Zeithaml, V. A., Bitner, M. J., \& Gremler, D. D. (2012). Services Marketing: Integrating Customer Focus Across the Firm (2nd ed.). McGraw Hill.

Zeglat, D., Shrafat, F., \& Al-Smadi, Z. (2016). The Impact of the E-Service Quality (E-SQ) of Online Databases on Users' Behavioural Intentions: A Perspective of Postgraduate Students. International Review of Management and Marketing 6(1), 1-10. 